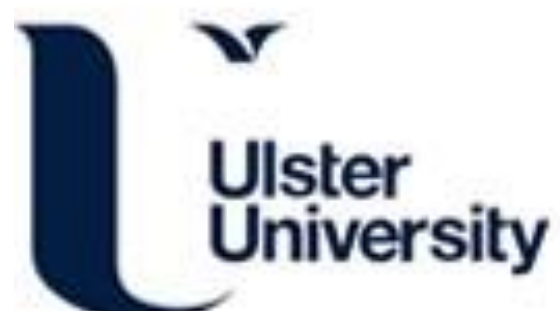

\section{Maintaining stability while boosting growth? The long-term impact of environmental accreditations on firms' financial risk and sales growth}

\author{
Ye, Y., Yeung, A., \& Huo, B. (2020). Maintaining stability while boosting growth? The long-term impact of \\ environmental accreditations on firms' financial risk and sales growth. International Journal of Operations and \\ Production Management, 40(12), 1829-1856. https://doi.org/10.1108/IJOPM-05-2019-0407
}

Link to publication record in Ulster University Research Portal

\section{Published in:}

International Journal of Operations and Production Management

Publication Status:

Published (in print/issue): 06/07/2020

DOI:

10.1108/IJOPM-05-2019-0407

\section{Document Version}

Author Accepted version

\section{General rights}

Copyright for the publications made accessible via Ulster University's Research Portal is retained by the author(s) and / or other copyright owners and it is a condition of accessing these publications that users recognise and abide by the legal requirements associated with these rights.

\section{Take down policy}

The Research Portal is Ulster University's institutional repository that provides access to Ulster's research outputs. Every effort has been made to ensure that content in the Research Portal does not infringe any person's rights, or applicable UK laws. If you discover content in the Research Portal that you believe breaches copyright or violates any law, please contact pure-support@ulster.ac.uk. 


\title{
Maintaining stability while boosting growth? The long-term impact of environmental accreditations on firms' financial risk and sales growth
}

\begin{abstract}
Purpose: In this research, we examine the impact of ISO 14001, an international environmental management accreditation, on the long-term financial risk and sales growth of firms.
\end{abstract}

Design/methodology/approach: We employ a quasi-experimental design and construct 682 treated and control firms that are matched using propensity score matching. We then test our hypotheses using the difference in difference model.

Findings: We find that, although ISO 14001 leads to lower financial risk, standard management systems such as ISO 14001 actually hinder the sales growth of firms, an unanticipated outcome. In particular, this trade-off worsens over time, becoming particularly more severe among firms who adopted ISO 14001 early and operate in less-polluting industries.

Research imitations/implications: We present a hidden side of environmental accreditations, indicating a potential trade-off in the long-term efficacy of environmental standard management systems.

Practical implications: Firms must be cautious about adopting environmental management systems. Over time, a focus on environmental certification could potentially hinder firms' long-term growth. Firms should also be aware of certification timing and the level of industrial pollution to resolve the tension. 
Originality/value: This research is one of the first studies demonstrating that environmental accreditations result in a trade-off between reducing financial risk and improving sales growth. Keywords: environmental accreditations; ISO 14001; financial risk; sales growth; trade-off Paper Type: Research Paper 


\section{Introduction}

Maintaining stability and boosting growth is a critical managerial task for firms to gain a competitive advantage in the market. According to Ortiz-de-Mandojana and Bansal (2016), ensuring low financial risk and strong sales growth over the long term requires organisational resilience, a critical measure of competitive advantage. Financial risk refers to the idiosyncratic volatility of stock prices associated with firm-specific events, such as an environmental incident or a product recall (Bansal and Clelland, 2004). A high level of financial risk indicates high unpredictability of a firm's future performance (Bansal and Clelland, 2004; Luo and Bhattacharya, 2009; Lam, 2018), whereas a low level means convenient access to finance and steady cash flows (Shin and Stulz, 2000). In contrast, sales growth refers to the rate of change in sales volume (Mishina et al., 2004). A high level of sales growth indicates that a firm can take full advantage of its existing resources and opportunities to enhance its impact.

In the operations management (OM) field, standard management systems are often employed to continuously improve operational processes (Ivanova et al., 2014). Across the board, it is taken for granted that certification assures better performance. However, in a dynamic environment where firms struggle to survive and grow, the efficacy of standard management systems in achieving a competitive advantage remains unclear. When it comes to standard management systems, in terms of promoting sustainable OM, it is unknown whether good intentions will translate into a win-win paradigm. In this way, in this paper, we focus on ISO 14001, an international environmental management accreditation, and its 
impact on stability and growth over time (Sharfman and Fernando, 2008).

In linking firms' adoption of ISO 14001 with financial risk and sales growth, we use an organisational capability perspective to depict how ISO 14001 adoption may contribute to firms' competitive advantage. We argue that improved financial risk and sales growth stem from the change in the relative competitive positions of both ISO 14001 adopting and non-adopting firms. Following the rationale of Zheng et al. (2015) and Ortiz-de-Mandojana and Bansal (2016), we propose that ISO 14001 accreditation may facilitate two types of capabilities_-buffering and enabling. Buffering capability is critical for sheltering firms from threats and reducing volatility, whereas enabling capability is essential for exploiting opportunities and stimulating growth. Such benefits accrue over time, given that firms accumulate more experience the longer they conform to ISO 14001. The findings of Ortiz-de-Mandojana and Bansal (2016) well support the rationale that social and environmental practices contribute to improved financial volatility and sales growth over the long term. Nonetheless, the facilitating role of ISO 14001 is questionable with regard to both the buffering and enabling capabilities, partially owing to the limited scope of the standard management system.

Firms based in different contexts will likely gain varied benefits from adopting ISO 14001, which highlights the importance of contextual factors in ISO 14001. The timing of certification and type of industry involved may affect the efficacy of firms' buffering and enabling capabilities to gain competitive advantages (Sousa and Voss, 2008). For example, by obtaining ISO 14001 certification early, firms can distinguish themselves through a 
first-mover advantage over their rivals, whereas those adopting ISO 14001 later than their peers may be hindered from exploiting buffering and enabling capabilities (Bansal and Hunter, 2003; Su et al., 2015). Likewise, firms operating in high-polluting industries encounter substantial environmental risk and stringent regulatory control; thus, they can make better use of their ISO 14001 certification to safeguard against risk and take advantage of valuable opportunities. Firms in less-polluting industries with less environmental risk and loose regulatory control would reap fewer benefits from adopting ISO 14001.

We examine our hypotheses using data from listed Chinese manufacturing firms for three reasons: First, China, as "the world's factory," undertakes substantial production tasks around the globe. Rapid industrialisation and economic development can cause severe environmental pollution; however, the number of Chinese firms adopting ISO 14001 has been increasing dramatically, reaching over 1.6 million in 2016 and accounting for half of the total firms that have adopted it worldwide. Thus, understanding the success of ISO 14001 implementation is critical. Second, there is a stereotype about Chinese manufacturers that they are narrow-minded and lax in instituting operational processes. This cynical view places Chinese manufacturers at additional risk and constrains their growth potential. Understanding how ISO 14001 certification may enable firms' stability and growth has strategic merit for Chinese firms. Third, previous studies about ISO 14001 and financial performance have been mainly focused on the Western context, and the few studies on China only use survey methods (Feng and Wang, 2014; He et al., 2015). This study bridges this gap by using panel data from an archival database and employing econometric techniques to address 
endogeneity.

In summary, in this study, we focus on the following three primary research questions: (1) Do firms that adopt ISO 14001 reduce their financial risk relative to their peers? (2) Do firms that adopt ISO 14001 improve their sales growth relative to their peers? And (3) Does the certification timing and the industrial pollution level of firms moderate the relationships?

This study makes several contributions to the literature. First, we question the implicit knowledge in OM that standard management systems necessarily improve performance by revealing a potential tension underlying the adoption of ISO 14001. Second, we construe the effect of ISO 14001 on the development of firms' buffering and enabling capabilities from an organisational capability perspective. Third, we uncover the importance of the relationship of ISO 14001 adoption to certification timing and industry type and also indicate that the tension in adoption depends on contextual factors.

\section{Literature review and hypotheses development}

ISO 14001 adoption

ISO 14001 is a voluntary environmental management system and, notably, does not set a specific goal for a firm (Melnyk et al., 2003). The intention behind ISO 14001 is to improve firms' environmental performance by carrying out a series of process improvement activities (Potoski and Prakash, 2005a; Aravind and Christmann, 2011; Yu and Ramanathan, 2015). ISO 14001 requires firms to invest significant resources in improving overall operational processes and making an active commitment to environmental management (Boiral et al., 2017). According to a US survey, if a firm owning 10 factories adopts ISO 14001, the initial 
costs amount to $\$ 250,000-\$ 1,000,000$ (Potoski and Prakash, 2005b). Additional maintenance costs are also substantial and include investing more time and money, hiring external experts, and paying continuation fees.

In implementing ISO 14001, firms must follow a well-designed guideline and meet a set of operational process requirements (Bansal and Hunter, 2003; Boiral, 2007; Aravind and Christmann, 2011). First, firms must thoroughly review their operational processes and identify possible negative impacts on the environment. Second, they should formulate an environmental management plan, determine corresponding goals, and ensure managers' full commitment. Third, they should implement policies according to the specified procedures and objectives. During the implementation stage, it is critical to communicate with, empower, and provide sufficient training to employees as well as maintain explicit records. Fourth, firms must conduct environmental audits regularly to correct deviations in advance and ensure the achievement of established goals. Finally, firms should review their entire system and continuously improve their level of environmental management. The implementation follows a plan-do-check-act cycle, a continuous improvement process in terms of the system, structure, policy, and goal.

An organisational capability perspective on ISO 14001 adoption

We employ the organisational capability perspective to understand the relationship between ISO 14001 adoption and financial risk and sales growth. Organisational capabilities refer to firms' capacity to use a combination of resources effectively to achieve a competitive advantage (Wernerfelt, 1984; Amit and Schoemaker, 1993; Collis, 1994). Such capabilities 
consist of distinct and sophisticated routines that represent collective and social embeddedness (Sanchez and Mahoney, 1996; Dosi et al., 2000; Schreyögg and Kliesch-Eberl, 2007). Many studies have highlighted the significance of environmental management practices in developing organisational capabilities (Aragón-Correa and Sharma, 2003; Sharma and Ruud, 2003; Dangelico and Pontrandolfo, 2015; Albertini, 2019; He and Shen, 2019) . For instance, Dangelico and Pontrandolfo (2015) suggested that "being green" is manifested in firms' ability to implement environmental actions and develop environmental collaborations. He and Shen (2019) proposed that ISO 14001 certification facilitates internal resource management capabilities, including resource utilisation, accumulation, and allocation.

Accordingly, in this study, we link ISO 14001 adoption to organisational capabilities because it enables firms to implement a series of process improvement activities. During this process, firms can acquire an understanding of operational processes, develop shared values on environmental protection, provide extensive training to employees, and attach importance to the audit, review it, and conduct continuous improvement of the system (Bansal and Hunter, 2003; King et al., 2005). Moreover, ISO 14001 implementation embeds positive routines in organisational processes, wherein firms accumulate unobserved and unique capabilities over time. As such, ISO 14001 adoption can facilitate improved organisational capabilities and result in competitive advantages to firms.

We propose that ISO 14001 fosters two types of capabilities-buffering and enabling - such that firms can attain competitive advantages in the market (Zheng et al., 2015; Ortiz-de-Mandojana and Bansal, 2016). Here, buffering capability is defined as firms' ability 
to safeguard against disruptions and mitigate their adverse impacts, whereas enabling capability refers to firms' ability to search for and exploit growth opportunities and retain essential resources. ISO 14001 implementation helps firms to set standard procedures, diagnose operational problems, take corrective actions in a continuous improvement cycle, and improve relationships with stakeholders, all of which improve buffering capability (Lam, 2018). Furthermore, firms that implement ISO 14001 can establish a long-term orientation to organisational members, provide extensive training to employees, and gain access to new customers and markets, thus developing their enabling capability.

The impact of ISO 14001 on long-term financial risk

Risk denotes that the outcome of a situation is unpredictable (Miller and Bromiley, 1990; Sitkin and Pablo, 1992). Financial risk is assessed through volatility or disturbance of stock prices, which indicates the degree to which investors are undecided about a firm's future cash holdings (Bouchaud and Potters, 2000; Luo, 2007). Firms with minimal financial risk are competitive because they have more flexible strategic options (Chatterjee et al., 1999), more convenient access to capital (Shin and Stulz, 2000), and more sound future expectations (Bansal and Clelland, 2004).

Financial risk can be classified into two types - systematic risk and unsystematic or idiosyncratic risk (Bansal and Clelland, 2004; Ang et al., 2006; Luo, 2007). Systematic risk refers to the volatility in stock prices due to fundamental changes in the market such as risk rate adjustment and currency inflation (Bansal and Clelland, 2004). Systematic risk exerts symmetric influence on all firms in the market, whereas unsystematic risk refers to stock 
price volatility caused by firm-specific incidents (Bansal and Clelland, 2004) such as environmental incidents (Lo et al., 2018), supply chain disruptions (Hendricks et al., 2009), and product recall announcements (Zhao et al., 2013). It is widely acknowledged that managers should be more concerned about unsystematic risk, which accounts for a high proportion of overall volatility in stock prices (over 80\%) and can have a significant impact on firms' financial health (Bansal and Clelland, 2004). In this study, we refer to financial risk as unsystematic risk due to its more overwhelming impact.

The efficient market hypothesis argues that stock prices are sensitive to events that significantly affect firms, given that the information is released (Brown et al., 1988). For instance, operational misconduct, such as discharging toxic chemicals into rivers, may influence investors, who anticipate associated legal liabilities regarding buying and selling shares, thus influencing firms' stock prices and financial volatility (Bansal and Clelland, 2004). Therefore, reducing the likelihood of operational disruption is crucial for minimising financial risk. From an organisational capability perspective, we argue that adopting ISO 14001 endows firms with the buffering capability to reduce the likelihood of adverse events that may affect variance in stock prices. Buffering capability is manifested in firms' ability to reduce the possibility of operational disruption and alleviate its adverse influence. ISO-14001-certified firms tend to follow a standard management procedure, develop a proactive mindset to notice hazards ad hoc, establish a routine to correct for deviations, and involve a process ensuring continuous improvement (Darnall and Edwards, 2006). In this way, firms are equipped with a capacity for detecting changes, anticipating problems, 
learning from mistakes and adjusting to various conditions, thus reducing financial risk (Ortiz-de-Mandojana and Bansal, 2016; Zheng et al., 2015).

ISO 14001, as an international standard management system, provides a step-by-step implementation guide based on best practices (Ivanova et al., 2014). By complying with this standard, firms should be able to eliminate a large proportion of hazards in daily operations. Second, the implementation of ISO 14001 leads to an overall assessment of organisational structures, processes, and knowledge. Firms can gain an in-depth understanding of their operations and prevent unreasonable, irregular, and unsafe processes as early as possible, thus reducing the likelihood of disruption (Kitazawa and Sarkis, 2000). Third, the continuous improvement process facilitates the detection and correction of problems on a long horizon. Firms can form an audit team to regularly assess conformity with certification requirements and identify deviations from established goals. This team can evaluate performance data and talk to frontline workers about the actual implementation. If any problems are detected, the team can take prompt measures to fundamentally solve them. Additionally, firms can attain an insurance-like moral capital and a higher level of legitimacy from stakeholders by adopting ISO 14001 certification (Bansal and Clelland, 2004; Koe Hwee Nga, 2009), which allow them to obtain disproportionate support and build more flexibility (Godfrey et al., 2009; Flammer, 2013).

In contrast, firms not adopting ISO 14001 will not be able to develop a buffering capability, thus becoming more vulnerable to disruptions and higher financial volatility. Overall, we expect that ISO 14001 adoption enhances buffering capability such that firms can 
better anticipate possible disruptions and mitigate adverse outcomes relative to their peers. As a result, adopting firms are less vulnerable to financial risk than those non-adopting. Thus, we hypothesise the following:

H1: ISO 14001 adoption leads to relatively lower long-term financial risk compared to non-adoption.

The impact of ISO 14001 on sales growth

Following a similar rationale, ISO 14001 implementation exposes new opportunities and attracts valuable resources, thereby enhancing enabling capability. First, firms that adopt ISO 14001 cultivate a long-term orientation to the development of resources, technologies, and routines, such that they become well prepared for novel opportunities and challenges (Ortiz-de-Mandojana and Bansal, 2016).

Second, ISO 14001 implementation involves substantial training of employees, resulting in well informed and committed employees more capable of detecting and seizing market opportunities. At the same time, ISO 14001 implementation requires intensive involvement of various employees and functional departments (Kitazawa and Sarkis, 2000; Bansal and Hunter, 2003). For example, the procurement department should work with the production department to facilitate eco-product design. The production department should further collaborate with the sales department to ensure that customers' environmental needs are satisfied. With comprehensive internal collaboration, firms can fully exploit their capabilities to utilise every potential opportunity and expand their market.

Third, adopting ISO 14001 can be an essential approach for firms to attract and retain 
resources. ISO 14001 certification symbolises firms' legitimacy in the market and institutional environments (Aguilera et al., 2007). For instance, reputed companies such as Ford and General Electric mandate that their suppliers obtain ISO 14001 certification (Darnall and Edwards, 2006). ISO 14001 can act as an environmental passport to enter new markets, sign preferential trade agreements, and pay preferential tariffs (Wang and Qian, 2011). Therefore, firms can export to previously inaccessible markets and improve their sales growth (Menguc et al., 2010). Additionally, an increasing number of customers have realised the significance of environmental protection such that they are motivated to purchase products from responsible firms (Flammer, 2013). ISO-14001-certified firms can attract such environmentally aware customers, thus expanding the market size (Bansal, 2003; Delmas and Montes-Sancho, 2011). Non-adopting firms, however, may lose valuable opportunities and market resources to their competitors, resulting in a lower rate of sales growth. To summarise, ISO 14001 adoption facilitates firms' detection and utilisation of opportunities, as well as the retention of essential resources that enhance firms' enabling capability. Informed by the above discussion, we propose our second hypothesis:

H2: ISO 14001 adoption leads to relatively higher long-term sales growth compared to non-adoption.

The moderating impact of certification timing and industry pollution level

Contingency theory emphasises "fit" between organisational practices and the environment (Fry and Smith, 1987; Sousa and Voss, 2008; Zhang et al., 2012). To understand how ISO 14001 leads to maximised benefits, it is necessary to investigate how different 
contexts shape the efficacy of ISO 14001 implementation (Cañón-de-Francia and Garcés-Ayerbe, 2009; Su et al., 2015; Lucas and Noordewier, 2016).

Previous studies have highlighted the roles of certification timing and industry pollution levels in ISO 14001 implementation, most of which found that firms' early initiatives led to improved performance. For example, Klassen and McLaughlin (1996) suggested that firms who won an environmental award for the first time saw increased financial performance. Lo et al. (2013) found that firms' performance improved according to how early they had obtained ISO 9001 certification. Flammer (2013) indicated that positive reactions of the market to environmental practices weakened over time. Su et al. (2015) noted that early adoption of ISO 14001 led to firms gaining a competitive advantage.

In addition, many studies have focused on industry pollution levels. For instance, Lucas and Noordewier (2016) found that firms in high-polluting industries received more benefits from adopting environmental practices. Cañón-de-Francia and Garcés-Ayerbe (2009) indicated that the market does not favour firms in light-polluting industries obtaining ISO 14001 certification. However, some studies have noted that firms in high-polluting industries gain fewer advantages from environmental practices. Sadovnikova and Pujari (2017) indicated that inter-firm collaboration in environmental practices was less efficient in high-polluting industries. Klassen and McLaughlin (1996) also discovered that the positive relationship between winning environmental awards and financial performance was weakened in high-polluting industries. Despite these extensive studies, the impact of certification timing and industry pollution levels on the effectiveness of ISO 14001 adoption 
from the organisational capability perspective is an unexplored topic.

We suggest that certification timing would impact the efficacy of firms' buffering and enabling capabilities. Obtaining certification early allows first-mover advantages (i.e., the additional performance benefits firms gain by taking competitive actions earlier than their peers; Bansal and Hunter, 2003; Russo, 2009; Su et al., 2015). In the diffusion process of implementing ISO 14001, the level of isomorphism among firms grows. Firms obtaining early certification effortlessly attain valuable and heterogeneous capabilities, thus distinguishing themselves in the market. Specifically, when only a few firms embrace standard management systems, most become vulnerable to disruptions arising from complex and disordered processes. By implementing ISO 14001 early, adopters understand their operational processes, identify and make adjustments for problems, and obtain stakeholder favour, thus developing a more robust buffering capability. From a competitive view, such a capability is heterogeneous in the market, and, therefore, such firms would occupy a dominant position and have lower financial risk. Late adopting firms, however, may not outperform their peers with respect to ISO 14001 implementation. For them, their buffering capability becomes homogenous in the market and does not yield a competitive advantage in terms of financial risk.

Similarly, early adoption of ISO 14001 is critical for firms' enabling capability. Being pioneers in implementing ISO 14001, early adopters have a golden opportunity to utilise substantial resources, enter global markets, and attract new customers, thus gaining promising market opportunities ( $\mathrm{Su}$ et al., 2015). In competition with rivals, firms that 
outpace others can capture the market and implement various growth initiatives. In contrast, late adopters lag behind and have to compete for market residuals, thus reaping fewer benefits. Thus, relative to other firms, those obtaining early ISO 14001 certification are distinct in that they can take advantage of their capabilities to mitigate risk and seize opportunities (Bansal and Hunter, 2003; Su et al., 2015). Thus, we hypothesise the following:

H3a: The impact of ISO 14001 in reducing financial risk will be higher for firms obtaining certification earlier than later (relative to their peers).

H3b: The impact of ISO 14001 in improving sales growth will be higher for firms obtaining certification earlier than later (relative to their peers).

Likewise, the level of industrial pollution moderates the significance of the two capabilities. We argue that adopting ISO 14001 could lead to more significant competitive advantages in high-polluting industries (Cañón-de-Francia and Garcés-Ayerbe, 2009; Lucas and Noordewier, 2016). These industries consist of textile, chemical, and food, and they discharge massive toxic emissions due to the nature of their products (Heinkel et al., 2001). Firms in high-polluting sectors are more affected by government monitoring and regulation (Varadarajan, 2017) and are naturally exposed to a higher level of regulatory, operational, and financial risk (Semenova and Hassel, 2008). ISO 14001 certification prepares firms with a buffering capability to foresee disruptions and cope with new problems; this capability is essential for high-polluting industries. Thus, adopting ISO 14001 is of enormous significance to these firms to fully exploit their buffering capability (Barnett and King, 2008). In light-polluting industries with relatively low inherent risk and loose environmental 
monitoring, however, buffering capability may not play an essential role in eliminating financial risk.

In contrast, firms in high-polluting industries that adopt ISO 14001 benefit more through attracting valuable resources and entering new markets, thus promoting their enabling capability. These firms generally face more environmental constraints and are less acceptable by the market (Semenova and Hassel, 2008). Adopting ISO 14001 certification thus helps them transcend restrictions, gain access to new opportunities, and outperform their rivals. These firms are more likely to win orders from in demand suppliers and enter elite markets before their competitors. Moreover, in high-polluting industries, firms that have implemented ISO 14001 are more attractive to consumers who perceive their buying behaviour as a matter of environmental protection (Barnett and King, 2008). However, firms in light-polluting industries are less distinguishable from each other in terms of pollution level and are more easily certified; ISO 14001 implementation thus generates fewer benefits for them. To summarise, firms that adopt ISO 14001 in high-polluting industries gain stronger competitive advantages than their peers. Therefore, we propose the following hypothesis:

H4a: The impact of ISO 14001 on reducing financial risk will be greater for certified firms in high-polluting than low-polluting industries (relative to their peers).

H4b: The impact of ISO 14001 on improving sales growth will be greater for certified firms in high-polluting than low-polluting industries (relative to their peers).

\section{Methodology}




\section{Data collection}

To examine the hypotheses proposed in this study, we focus on firms in the manufacturing sector (C13-C43) that are listed in Shanghai and Shenzhen A-share stock markets. Chinese firms serve as our research objective for several reasons. In the first place, China has severe environmental problems owing to industrial pollution. Second, we have access to the financial and operational database of Chinese-listed firms, along with the ISO certification data. Third, the majority of existing studies use survey data to analyse the relationship between environmental practices and environmental performance in China, whereas this study uses archival data and will thus deepen the understanding of the value of ISO 14001 certification.

In this study, we focus on firms in the manufacturing sector, which account for the majority of sources of pollution. From 2004 to 2016, China had 2,100 listed manufacturing firms and 27,300 firm-year observations. The data on ISO 14001 certification are from the National Certification and Accreditation Information Public Service Platform, an official online database that records every certification obtained by firms in China. Because one firm may have multiple certified plants or subsidiaries, we record the first ISO 14001 certification, following the conventional approach of previous studies (Corbett et al., 2005; Naveh and Marcus, 2005). We compile the certification data with financial data from the China Stock Market \& Accounting Research Database; we found 1,318 firms have adopted the ISO 14001 certification and 782 had not.

Because the combination of propensity score matching (PSM) and difference in 
difference (DID) requires data points before and after the year of ISO 14001 adoption, we exclude samples that lack such time points.

\section{Measures}

Dependent measures

Financial risk. We employ the Fama-French three-factor model to assess a firm's idiosyncratic risk (Bansal and Clelland, 2004; Luo and Bhattacharya, 2009). Compared to the market model, the three-factor model offers more robust and reliable estimates. Specifically, we estimate the following model for firm $i$ in day $t$ :

$$
R_{i t}-R_{f t}=\beta_{0 i}+\beta_{1 i} \cdot\left(R_{m t}-R_{f t}\right)+\beta_{2 i} \cdot S M B_{t}+\beta_{3 i} \cdot H M L_{t}+\varepsilon_{i t}
$$

where $R_{i}$ is the actual stock return, $R_{m}$ is the market portfolio return, $R_{f}$ is the risk-free return rate, $S M B$ is the small minus large market capitalisation, and $H M L$ is the high minus low book-to-market ratio. We exclude sample firms that lack 180 days of stock return data in a year. We also estimate the model for each firm in each year and obtain the annualised standard deviation of the residual (RMSE) as the measure for idiosyncratic risk.

Sales growth. This is measured by the annual rate of change in the sales volume each year. A high level of sales growth indicates that firms can utilise substantial resources and capabilities to expand and succeed (Eisenhardt and Martin, 2000; Zheng et al., 2015).

$$
\frac{\left(\text { Sales }_{t}-\text { Sales }_{t-1}\right)}{\text { Sales }_{t-1}}
$$

\section{Independent Measures}

ISO 14001. This is measured via a dummy variable, which is coded as " 1 " in the year of adoption. We identify firms adopting ISO 14001 from an official platform and verify the data 
with firms' annual corporate social responsibility (CSR) reports.

\section{Matching Variables}

Based on the literature review, we include a series of determinants of ISO 14001 adoption as matching variables in the PSM.

ISO 9001 and OHS 18001. Firms with standard management systems, such as ISO 9001 (quality management systems) and OHS 18001 (safety management systems), can easily integrate ISO 14001 into their existing routines (Casadesus et al., 2008; Fernández-Muñiz et al., 2012; Heras-Saizarbitoria and Boiral, 2013). Established management systems of ISO 9001 or OHS 18001 demonstrate firms' comprehensive capabilities to meet the requirements of ISO 14001 (Toffel, 2005). ISO 9001 and OHS 18001 are coded as "1" in the years that firms obtained these certifications. The data for these management systems come from the same source as the ISO 14001 certification.

Cross-listed. Whether a firm is listed in foreign stock markets will influence the likelihood of obtaining ISO 14001 certification (King et al., 2005; Peng and Su, 2014; Baek, 2017). Foreign investors might hold higher requirements for environmental management and exert added pressure on firms to adopt ISO 14001. In contrast, the level of information asymmetry between firms and overseas investors is more severe, and, thus, obtaining ISO 14001 certification is a valuable signal that reflects firms' commitment to environmental protection. We measure firms' being cross-listed by whether a firm is listed in Hong Kong or US stock markets as a dummy variable.

Slack. Extensive studies have indicated that slack-rich firms are willing to invest in 
projects whose benefits are uncertain (Bowen, 2002; Fernández-Muñiz et al., 2012; Aguilera-Caracuel et al., 2015). We identify financial slack as unutilised resources that are readily available for firms to meet short-term needs and opportunities (Bourgeois and Singh, 1983; Daniel et al., 2004). Slack is measured using current assets minus inventories divided by current liabilities (Palmer and Wiseman, 1999).

Age. The probability of firms obtaining ISO 14001 certification may increase with firm age (Hudson and Orviska, 2013; Baek, 2017). Compared to younger firms, older firms adopt more mature environmental technology and face fewer financial constraints, which can influence their decisions whether to adopt ISO 14001 (Darnall et al., 2010). Firm age is measured by the number of years from the establishment of the firm to the current year (logarithm transformation).

Profitability. Enhanced profitability may precede ISO 14001 adoption. Firms that demonstrate a high level of return on assets (ROA) and return on equity (ROE) can allocate more financial resources to obtaining certification (Heras-Saizarbitoria et al., 2011b; Baek, 2017; Li et al., 2017). That is to say, firms may adopt ISO 14001 because they can afford to do so. ROA and ROE are defined as profit divided by total assets and profit divided by equity, respectively.

Leverage. Firms that show a high level of financial leverage would be more risk-aversive and express additional concerns about environmental management (Przychodzen and Przychodzen, 2015; Baek, 2017). Leverage is measured by the ratio of total liabilities to total assets (Aivazian et al., 2005). 
Size. Firm size may be an essential determinant for adopting ISO 14001 (Nishitani, 2009). Large firms are more visible such that they are under increased pressure from multiple stakeholders to adopt environmental systems. Moreover, large firms possess more resources to bear the substantial costs of ISO 14001 adoption than small firms. We use sales volume (logarithm transformation) as the measure of firm size.

Inventory turnover. Firms with high operational efficiency are more capable of accommodating existing processes to new management systems (Fryxell et al., 2004; Heras-Saizarbitoria et al., 2011a). We employ inventory turnover as a proxy for firms' internal efficiency in managing operational flows, given that it captures the speed of transforming raw materials into finished products (Rabinovich et al., 2003; Xue et al., 2012). Inventory turnover is the ratio of costs of sold goods to the average inventory level (Gaur et al., 2005).

CSR disclosure. CSR disclosure refers to the information a firm discloses about its environmental and social impact, as a means to exemplify its values and orientation (Campbell, 2004; Reverte, 2009). We suggest that firms that publish CSR reports attach greater importance to stakeholder demands as well as environmental initiatives; thus, they are proactive in obtaining ISO 14001 certification (Bansal and Hunter, 2003; Chen et al., 2018). Although measures for environmental orientation or environmental performance are not available in China, we observe whether a firm provides a CSR report in a year as an alternative proxy.

Other variables. Finally, we include delayed dependent variables for more precise matching, adding the means of one- and two-year-delayed financial risk and sales growth. In addition, we include year, industry, and region as other covariates. Table I shows the summary 
statistics of the variables used for PSM, and Table II is the corresponding correlation table. -Insert Table I and II about here-

Propensity score matching (PSM) and difference in difference (DID)

To answer the research question of whether ISO 14001 leads to improved financial risk and sales growth for adopting firms compared to non-adopters in the same period, we first employ PSM to construct treated and control groups that are matched, and then we use DID to examine the treatment effect. In econometric studies, combining PSM and DID is a common strategy to control for both observed and unobserved variances between groups and eliminate the impact of endogeneity.

PSM

PSM is a technique to generate matched treated and control groups with similar covariates. The probability of a firm adopting ISO 14001 depends on a series of observable covariates in the pre-adoption period, whereas other between-group variances are randomly distributed (Rosenbaum and Rubin, 1983).

The application of PSM must meet several criteria (Toffel, 2005; Levine and Toffel, 2010; Lechner, 2011). First, the data source for the adoption and non-adoption groups should be the same. Second, the covariates used to estimate the propensity scores should be comprehensive. Third, the distribution of the two groups should be similar. We address these concerns by collecting the sample firms from the same data sources, identifying adoption determinants based on an extensive literature review and using one-to-one nearest-neighbour 
matching within a caliper of 0.02 for accurate matching.

The first step in PSM is using the probit model to estimate the propensity scores. We include a set of adoption determinants, as elaborated above. After obtaining the propensity scores, we construct a matched sample using the psmatch2 command in STATA (Leuven and Sianesi, 2018). We implement the nearest-neighbour matching with a caliper of 0.02 to construct matched samples. Each adopting firm is matched to a non-adopter having the closest propensity score in the year of certification. In the third step, we examine the similarity between the treated and control groups (Smith and Todd, 2005), known as the balancing tests, to ensure that the two groups are indistinguishable before treatment.

$D I D$

DID is a common technique to evaluate the treatment effect of a policy or an initiative (Certo et al., 2017). It estimates how much change in the treated firms' group exceeds that in the control (Angrist and Pischke, 2008). Specifically, DID consists of the following four groups: treated group pre, treated group post, control group pre, and control group post. Let $D_{1}$ denote the difference in treated firms from $T_{2}$ to $T_{1}$, and let $D_{2}$ denote the difference in control firms from $T_{2}$ to $T_{1}$. The DID estimator is the difference between $D_{1}$ and $D_{2}$.

Using DID to draw a causal effect relies upon several assumptions (Lechner, 2011). The primary assumption is that of parallel trend, which suggests the trend in the treated and control groups is the same in the absence of treatment. The PSM in our study appropriately addresses the assumption that the covariates are balanced and the pretreatment trend is similar across the matched groups. The second assumption is that the pretreatment performance cannot 
be affected by the treatment. To ensure that the effect of ISO 14001 does not precede the base year, we additionally use year $t-2$ as the base year in the robustness test. Third, the controls included in the model are exogenous. Fourth, the treatment of one firm does not affect the outcome of another one; this is known as the stable unit treatment value assumption (SUTVA). Although DID has been commonly adopted in related studies that examine the effect of ISO certifications (Lo et al., 2009; Levine and Toffel, 2010; Lo et al., 2014; Gray et al., 2015), none discussed the SUTVA. To moderate this concern, we claim that firms adopting ISO 14001 leads to a change in their financial risk and sales growth relative to that of the non-adopters. We further discuss this issue in the limitations section.

We employ DID to examine the impact of ISO 14001 on financial risk and sales growth. We estimate the following model for firm $i$ in year $t$ :

$$
y_{i t}=\alpha_{i}+\beta_{1} \text { Treat }_{i}+\beta_{2} \cdot \text { Post }_{t}+\boldsymbol{\beta}_{3} \cdot \text { Treat }_{\boldsymbol{i}} \cdot \text { Post }_{\boldsymbol{t}}+\gamma \cdot X_{i t}+\delta_{t} \cdot \text { year }_{t}+\varepsilon_{i t}
$$

where $y_{i t}$ refers to financial risk or sales growth; $\alpha_{i}$ is the intercept for each firm, and Treat and Post are dummy variables, coded as " 1 " and " 0 " for the treated and control groups, respectively. $\beta_{3}$ estimates the interaction between Treat and Post, representing the effect of ISO 14001, and year ${ }_{t}$ represents the year dummies. We estimate the model using ordinary least squares (OLS) with firm fixed effects.

In addition, we include three dummies coded as " 1 " in $t=0$ to $t=2, t=3$ to $t=5$, and $t$ $=6$ to $t=8$ to investigate the impact of ISO 14001 adoption on financial risk and sales growth in different periods. In this way, we are able to present a long-term perspective to understand the outcomes of ISO 14001 adoption. 
To examine the moderating effects of certification timing and industrial pollution level, we adopt multi-group DID. Firms' certification timing is measured by the relative timing of ISO 14001 adoption compared to rivals in the same industry (Corbett et al., 2005; Su et al., 2015); firms are divided into the early or late adoption group accordingly. The industrial pollution level is based on an industrial directory issued by the Ministry of Environmental Protection in China, which classifies 14 industries into high- and low-polluting ones.

\section{Results}

PSM results

Table III presents the probit model results for estimating propensity scores, indicating the probability of firms adopting ISO 14001. Each marginal effect shows the change in adoption probability when the independent variable changes by one unit. Our results reveal that the likelihood of obtaining ISO 14001 certification is related to having already adopted ISO 9001 or OHS 18001, low financial leverage, young age, large size, and low inventory turnover. Insert Table III about here-

Based on propensity scores, we conduct one-to-one matching in the year of certification with a caliper of 0.02 and construct a total of 682 treated and control firms that are matched. The result of the balancing test (Table IV) indicates a good quality of matching (Sianesi, 2004). First, the pseudo R-squared drops significantly from 0.196 to 0.058 after the matching procedure, suggesting that the matched groups are similar in terms of the covariates before treatment. Second, the balancing test of covariate differences in the matched sample indicates small differences between the treated and control groups. Of the 13 metrics, one 
differs at the 0.05 level and one differs at the 0.1 level, which is comparable to the results found in Levine and Toffel (2010). Third, the values of standardised bias drop significantly after matching: the means (medians) of standardised bias decline from $10.3 \%(8.1 \%)$ to $4.8 \%$ (3.7\%). Fourth, the trends of financial risk and sales growth in the pretreatment period between matched firms are homogenous.

-Insert Table IV about here

\section{DID results}

Table V shows the results of DID regarding the impact of ISO 14001 on financial risk and sales growth. Because we adopt a firm-fixed effect OLS model, the Treat variable is omitted because it is time-invariant. In columns (1) and (3), the results suggest that ISO 14001 adopters significantly reduce their financial risk by $0.13 \%$ compared to that of non-adopters. A counter-intuitive result is that ISO 14001 adopters significantly decrease their sales growth by $5 \%$ compared to that of non-adopters.

Based on year-to-year comparisons in columns (2) and (4), we find that the impacts of ISO 14001 adoption on financial risk and sales growth enlarge over time, suggesting a long-term influence of ISO 14001 adoption. In column (2), the results indicate that financial risk is increasingly undermined, from $0.11 \%$ in years $0-2$ to $0.21 \%$ in years $6-8$. Column (4) shows that the negative impact of ISO 14001 adoption on sales growth is also strengthened over time. In years $0-2$, the rate of sales growth between adopters and non-adopters is similar. However, adopters face a $4.8 \%$ and $9.5 \%$ reduction in sales growth compared to non-adopters in years 3-5 and years 6-8, respectively. The negative effect of ISO 14001 on sales growth 
increases over time and only appears three years after adoption. In summary, the results support $\mathrm{H} 1$ but reject $\mathrm{H} 2$.

-Insert Table V about here-

Table VI presents the multi-group DID comparison in examining the moderating effects of certification timing and industry pollution levels. Those firms adopting ISO 14001 early reduce financial risk by $0.19 \%$ compared to non-adopters; however, late adopters do not benefit from any reduced financial risk. In contrast, sales growth decreases by $5.7 \%$ and $4.5 \%$ for early and late ISO 14001 adopters, respectively, compared with non-adopters. The results imply that early certification would strengthen the negative impact of ISO 14001 on both financial risk and sales growth, supporting $\mathrm{H} 3 \mathrm{a}$ but rejecting $\mathrm{H} 3 \mathrm{~b}$.

As for the moderating effect of industrial pollution levels, the results show that adopter firms in high-polluting industries reduce their financial risk by $0.15 \%$ compared to non-adopters. In comparison, adopters in light-polluting industries have a $0.12 \%$ reduced financial risk compared to non-adopters. Thus, ISO 14001 adoption leads to a $4.4 \%$ and $4.8 \%$ decrease in sales growth in high- and light-polluting industries, respectively, compared to non-adoption. Conclusively, being in high-polluting industries strengthens the negative impact of ISO 14001 adoption on financial risk and weakens the negative impact on sales growth. The results support $\mathrm{H} 4 \mathrm{a}$ but reject $\mathrm{H} 4 \mathrm{~b}$. 
We conduct several tests to assess the robustness of the results. First, because certification can take 6 to 18 months to prepare (Corbett et al., 2005), we match on year $t-2$ to make sure the matching is free from the treatment. The result of an earlier base year yields a similar pattern, suggesting that the effect of treatment in the pretreatment period is not a serious concern.

Second, we alter proxies for the dependent variables and retest the model. Because financial risk and sales growth may show systematic variance in specific industries, we adopt industry-adjusted financial risk and sales growth (minus the median in an industry) and find the results unchanged. Furthermore, we adopt the market model to recalculate financial risk and use two years of sales growth, leading to similar results.

Third, we add more control variables in the DID model, including financial indicators (i.e., ROA, ROE and return on sales), which resulted in obtaining similar results. This suggests that the results are robust while considering other possible impacts.

Fourth, in examining the moderating effect of the industrial pollution level, the results may be affected by firm-level pollution levels. We include the number of environmental regulatory violations (industry-adjusted), which is a proxy for firm-level environmental pollution levels, as an additional control variable in testing $\mathrm{H} 4 \mathrm{a}$ and $\mathrm{H} 4 \mathrm{~b}$. The result of the moderating analysis remains the same.

\section{Extensions}

Observing that ISO 14001 reduces financial risk, it is necessary to investigate whether ISO 14001 adoption detracts from actual financial benefits (Lam, 2018). We examine two 
additional dependent variables, ROA and financial returns, but do not find a significant impact of ISO 14001 adoption on either of these variables in the DID model. Thus, we suggest that adopting ISO 14001 only decreases financial risk and does not affect financial benefits.

\section{Discussion}

The impact of ISO 14001 adoption on financial risk and sales growth

This study provides empirical evidence that ISO 14001 adoption decreases both financial risk and sales growth compared to non-adoption, and such impacts accrue in the long run. Our finding of decreased financial risk is consistent with most studies within the domain of environmental management. For instance, Bansal and Clelland (2004) found that firms with high environmental legitimacy had lower financial risk. Lam (2018) indicated that supply chain sustainable practices led to lower financial risk. Mishra and Modi (2012) suggested that socially responsible practices can decrease idiosyncratic risk. Obtaining ISO 14001 certification enables firms to follow standard management disciplines, diagnose underlying problems, improve operational processes continuously, and gain insurance-like protection, thereby enhancing their buffering capability of avoiding risk and minimising adverse impacts.

In contrast, the finding that ISO 14001 adoption negatively impacts sales growth, compared to non-adoption, contradicts the findings of most studies (Judge and Douglas, 1998; Chan, 2005; Menguc et al., 2010). ISO 14001 adoption hinders firms' enabling capability and constrains their growth potential. Our study's unique finding indicates a trade-off, in which ISO 14001 implementation leads to divergent outcomes. It is curious why ISO 14001 adoption only contributes to buffering capability while hampering enabling capability. 
We propose a tentative explanation wherein the limited scope of ISO 14001 practices hampers the development of enabling capability. Unlike social and environmental practices that involve a broad range of activities such as stakeholder relations, human rights, and green supplier management (Ortiz-de-Mandojana and Bansal, 2016), ISO 14001 certification follows a specific guideline and standard procedure, which may not be sufficient for deploying different types of resources and generating heterogeneous capabilities. Obtaining ISO 14001 certification requires firms to implement standard management practices that are narrowly defined, implying a "one size does not fit all" dilemma (Simpson et al., 2012; Hudson and Orviska, 2013). Compliance with the "best practices," as defined by ISO 14001, ensures firms' stable operations and minimises risks, thus improving buffering capability. Nevertheless, adhering to the standard guidelines cannot guarantee the enabling capability with regard to exploring new opportunities and retaining important resources. The development of one capability may bring rigidity or inflexibility to the firm, hindering the development of the other (Schreyögg and Kliesch-Eberl, 2007). Although ISO 14001 adoption improves buffering capability, firms might be locked into the mindset of being risk-aversive, thus reluctant to search for and exploit opportunities (Schreyögg and KlieschEberl, 2007). Even worse, the implementation of ISO 14001 is resource-consuming (Babakri et al., 2003), especially for Chinese firms less-experienced in institutionalised management systems (Zeng et al., 2008). The high costs may further constrain the deployable resources for market expansion.

Taken together, the findings suggest that ISO 14001 implementation is insufficient for 
firms to achieve competitive advantages, owing to a trade-off between buffering and enabling capabilities. Following the recall by Hollenbeck and Wright (2017), we propose a framework to illustrate how different levels of buffering and enabling capabilities lead to competitive advantages after the results are obtained (Figure 1). We argue that firms attaining a high level of both capabilities achieve competitive advantages through low financial risk and high sales growth relative to other firms (Block 4). The buffering (Block 2) and enabling (Block 3) advantage entail trade-offs. Although the buffering advantage is achieved by having both a low level of financial risk and sales growth relative to one's peers, the enabling advantage is characterised by both high financial risk and high sales growth. Firms that fail to develop either the enabling or buffering capability are regarded as being at a competitive disadvantage (Block 1), and such firms may show high financial risk and low sales growth. Thus, ISO 14001 adoption only facilitates the buffering advantage, wherein firms demonstrate low financial risk and low sales growth.

The moderating effects of certificate timing and industrial pollution levels

The examination of contextual factors reinforces the need to address "fit" in OM studies. We find that firms certified early achieve both reductions in financial risk and sales growth, compared to their rivals. The finding that early certification further decreases financial risk is consistent with that in existing studies (Klassen and McLaughlin, 1996; Delmas and Montes-Sancho, 2009; Flammer, 2013; Lo et al., 2013; Su et al., 2015). Early adopting firms gain a heterogeneous capability, build first-mover advantages to prepare for and defend against operational disruptions, and mitigate adverse impacts from risk, reinforcing the buffering 
advantage. However, firms certified late may not gain a buffering advantage due to the homogeneity of ISO 14001 adoption among rivals.

Obtaining ISO 14001 certification early further hampers firms' sales growth. Two reasons could explain this novel finding: First, earlier certified firms are more internally driven to adopt ISO 14001 and thus more seriously comply with the standard requirements of ISO 14001. Following the rationale in 5.1, we argue that these firms are more locked into the formal clauses and reduce their search for new opportunities. Second, firms certified early are in a market where environmental protection is not favoured, and consumers' environmental awareness has not been cultivated. The substantial devotion to ISO 14001 certification is less likely to transform into more market opportunities or an enlarged resource base. Those firms certified late, in contrast, are in a more developed market that values outstanding environmental management, and their sales growth is thus less affected. Therefore, early certification facilitates buffering capability to safeguard from risk, but it also undermines enabling capability to expand and capture market residuals, amplifying the conflict between stability and growth as opposing outcomes.

Our findings also show that ISO 14001 adoption by firms in high-polluting industries strengthens the mitigation of financial risk and lessens the harm to sales growth, compared to non-adoption. The finding that these firms decrease their financial risk is consistent with previous studies (Cañón-de-Francia and Garcés-Ayerbe, 2009; Lucas and Noordewier, 2016). Firms in high-polluting industries face greater financial, operational, and environmental risks. They encounter significant challenges in technology upgrades, process improvement, and 
waste management such that the significance of buffering capability is exaggerated.

We also find that the negative impact of ISO 14001 adoption on sales growth is weakened in high-polluting industries, compared to non-adoption. That is to say, the effect of weakened enabling capability due to ISO 14001 adoption is less so for firms in high- than low-polluting industries. Firms operating in high-polluting industries are generally confronted with more stringent regulatory requirements and stricter rules for market access. Obtaining ISO 14001 certification is crucial for these firms to address their market position and attain critical resources. In essence, we find that ISO 14001 adoption in high-polluting industries reconciles the conflict between growth and stability. Firms in high-polluting industries suffer less from the trade-off of ISO 14001 adoption, such that they can maintain stability while not losing many growth opportunities.

\section{Conclusion and implications}

In this study, we demonstrate that environmental accreditations have different impacts on financial risk and sales growth over the long term. Drawing from an organisational capability perspective, we propose two types of capabilities - enabling and buffering - to study the effects of ISO 14001 implementation. Considering the contextual factors, we suggest that early certification strengthens both the positive effects of ISO 14001 on financial risk and sales growth. Being in high-polluting industries strengthens the positive impact of ISO 14001 on financial risk while weakening the negative impact on sales growth.

\section{Theoretical contribution}

Theoretically, this study contributes to the understanding of the relationship between 
ISO 14001 adoption and performance. Previous studies investigated the impact of certification on environmental management or financial performance, but few have looked at underlying and long-term performance indicators such as financial risk and sales growth. In this study, we explore stability and growth as two major objectives of firms and suggest that ISO 14001 adoption leads to a trade-off, revealing an unanticipated outcome of ISO 14001 adoption.

In particular, we draw from organisational capability theory and propose the development of buffering and enabling capabilities from ISO 14001 implementation, unveiling a new perspective to understand the effects of ISO 14001 on organisations. This perspective interprets enabling and buffering capabilities as pivotal contributors to competitive advantages. Given the trade-off we have uncovered, our study is distinct from Ortiz-de-Mandojana and Bansal (2016) in that it addresses the limitation of ISO 14001 in promoting organisational capabilities and competitive advantages.

From a more general perspective, most OM researchers are unwavering supporters of applying standard management systems in organisations (Ivanova et al., 2014). However, the trade-offs behind adopting certifications is not well understood. For instance, Lo et al. (2014) indicated that, although OHS 18001 promoted worker safety, it also led to decreased worker productivity and reduced profits. Our study suggests that firms may be confined by the "best practices" and fall into a "one size does not fit all" dilemma. The significance of demonstrating these mixed aspects of certification and, more importantly, probing into the contingencies that influence efficacy, will allow OM scholars to use such instruments in 
different contexts.

\section{Managerial implications}

Managerially, in this study, we provide a convincing answer to a question that has long confused managers: what is the impact of ISO 14001 on the long-term resilience of firms? Our findings suggest that ISO 14001 adoption reduces financial risk while harming sales growth, implying a trade-off between buffering and enabling capabilities. Reducing financial risk is vital for stable development such that firms may focus on core technology, conduct innovative activities, and win competitive advantages in highly turbulent environments (Luo and Bhattacharya, 2009; Lam, 2018). However, rapid growth and sustained stability can be opposing objectives in implementing ISO 14001. Managers should find a balance to maximise the benefits of firms. Start-up firms seeking rapid expansion should be cautious about obtaining ISO 14001 certification. The requirements for ISO 14001 can involve much effort, and the standard management system may hinder firms' search for resources and opportunities. In contrast, for firms pursuing stability, ISO 14001 adoption can aid in systematically improving processes and gaining support from shareholders. Especially as some medium- or large-sized firms reached a bottleneck in regard to market expansion, adopting ISO 14001 would be beneficial for their long-term stability.

In addition, managers should be concerned about the contextual factors affecting the effectiveness of ISO 14001. The earlier a firm adopts ISO 14001, the more financial stability it gains, but the more it loses in sales growth. Concerning the timing of obtaining a certification, managers must recognise the trade-off in which stability and growth cannot be 
achieved simultaneously. In high-polluting industries, ISO 14001 adoption leads to more robust stability and fewer losses in sales growth. Hence, considering the level of pollution, firms in high-polluting industries may benefit more from ISO 14001 adoption because the conflict between stability and growth is reconciled.

\section{Limitations and directions for future studies}

Our study suffers from several limitations that may provide avenues for future research. First, we focus on the effect of ISO 14001 certification and collect covariates based only on this particular type of certification. It is beyond the scope of this study to examine the effects of other certifications (e.g., ISO 9001 and OHS 18001), although a simple analysis finds nonsignificant effects of ISO 9001 or OHS 18001 certifications on financial risk and sales growth. Future studies could focus on the roles of other certifications in facilitating organisational capabilities and testing the generalisability of our findings.

Second, the preparation for ISO 14001 adoption may take years of effort, especially for Chinese firms that lack experience in institutionalised management systems. Although we examine both $t-1$ and $t-2$ as the base years in PSM, we cannot exclude the possibility that the effect of ISO 14001 precedes the base year. Moreover, using a much earlier base year might hamper the parallel trend assumption for DID. We, therefore, encourage future researchers to employ other sophisticated econometric methods, such as generalised estimating equations, to examine the effects of ISO 14001 certification (Jayasinghe, 2016).

Third, although we focus on the impact of ISO 14001 implementation in a competitive view, our use of DID cannot establish a causal effect due to the SUTVA. One way to address 
this assumption is to include the spillover effects in the econometric model, such that the causal effect of ISO 14001 adoption can be isolated. Two types of spillover effects might occur. The adoption of ISO 14001 in one firm may decrease the value of it for competitors, indicating a negative spillover effect. It is also likely that firms learn from rivals' knowledge and experience about and adopting ISO 14001, thus having a positive spillover effect. Future studies could operationalise the spillover effects to satisfy the SUTVA requirements. 


\section{References}

Aguilera, R.V., Rupp, D.E., Williams, C.A. and Ganapathi, J. (2007), "Putting the s back in corporate social responsibility: a multilevel theory of social change in organizations", Academy of Management Review, Vol. 32 No. 3, pp.836-863.

Aguilera-Caracuel, J., Guerrero-Villegas, J., Vidal-Salazar, M.D. and Delgado-Márquez, B.L. (2015), "International cultural diversification and corporate social performance in multinational enterprises: the role of slack financial resources”, Management International Review, Vol. 55 No. 3, pp.323-353.

Aivazian, V.A., Ge, Y. and Qiu, J. (2005), "The impact of leverage on firm investment: Canadian evidence”, Journal of Corporate Finance, Vol. 11 No. 1-2, pp.277-291.

Albertini, E. (2019), "The contribution of management control systems to environmental capabilities", Journal of Business Ethics, Vol. 159 No. 4, pp.1163-1180.

Amit, R. and Schoemaker, P.J. (1993), "Strategic assets and organizational rent”, Strategic Management Journal, Vol. 14 No. 1, pp.33-46.

Ang, A., Hodrick, R.J., Xing, Y. and Zhang, X. (2006), "The cross-section of volatility and expected returns", The Journal of Finance, Vol. 61 No. 1, pp.259-299.

Angrist, J.D. and Pischke, J.-S. (2008), Mostly harmless econometrics: an empiricist's companion, Princeton University Press, Princeton, NJ.

Aragón-Correa, J.A. and Sharma, S. (2003), “A contingent resource-based view of proactive corporate environmental strategy", Academy of Management Review, Vol. 28 No. 1, pp.71-88.

Aravind, D. and Christmann, P. (2011), "Decoupling of standard implementation from certification: does quality of ISO 14001 implementation affect facilities' environmental performance?”, Business Ethics Quarterly, Vol. 21 No. 1, pp.73-102.

Babakri, K.A., Bennett, R.A. and Franchetti, M. (2003), “Critical factors for implementing ISO 14001 standard in United States industrial companies", Journal of Cleaner Production, Vol. 11 No. 7, pp.749-752.

Baek, K. (2017), "The diffusion of voluntary environmental programs: the case of ISO 14001 in Korea, 19962011”, Journal of Business Ethics, Vol. 145 No. 2, pp.325-336.

Bansal, P. (2003), "From issues to actions: the importance of individual concerns and organizational values in responding to natural environmental issues", Organization Science, Vol. 14 No. 5, pp.510-527.

Bansal, P. and Clelland, I. (2004), "Talking trash: legitimacy, impression management, and unsystematic risk in the context of the natural environment”, Academy of Management Journal, Vol. 47 No. 1, pp.93-103.

Bansal, P. and Hunter, T. (2003), "Strategic explanations for the early adoption of ISO 14001", Journal of Business Ethics, Vol. 46 No. 3, pp.289-299.

Barnett, M.L. and King, A.A. (2008), "Good fences make good neighbors: a longitudinal analysis of an industry self-regulatory institution”, Academy of Management Journal, Vol. 51 No. 6, pp.1150-1170.

Boiral, O. (2007), “Corporate greening through ISO 14001: a rational myth?”, Organization Science, Vol. 18 No. 1, pp.127-146.

Boiral, O., Guillaumie, L., Heras-Saizarbitoria, I. and Tayo Tene, C.V. (2017), “Adoption and outcomes of ISO 14001: a systematic review”, International Journal of Management Reviews, Vol. 20 No. 2, pp.411-432.

Bouchaud, J.-P. and Potters, M. (2000), Theory of financial risks, Cambridge University Press, Cambridge, UK. Bourgeois III, L.J. and Singh, J.V. (1983), “Organizational slack and political behavior among top management teams", Academy of Management Proceedings, Vol. 1, pp.43-47.

Bowen, F.E. (2002), "Does size matter? organizational slack and visibility as alternative explanations for 
environmental responsiveness", Business \& Society, Vol. 41 No. 1, pp.118-124.

Brown, K.C., Harlow, W.V. and Tinic, S.M. (1988), "Risk aversion, uncertain information, and market efficiency”, Journal of Financial Economics, Vol. 22 No. 2, pp.355-385.

Campbell, D. (2004), "A longitudinal and cross-sectional analysis of environmental disclosure in UK companies - a research note", The British Accounting Review, Vol. 36 No. 1, pp.107-117.

Cañón-de-Francia, J. and Garcés-Ayerbe, C. (2009), "ISO 14001 environmental certification: a sign valued by the market?", Environmental and Resource Economics, Vol. 44 No. 2, pp.245-262.

Casadesus, M., Marimon, F. and Heras, I. (2008), "ISO 14001 diffusion after the success of the ISO 9001 model", Journal of Cleaner Production, Vol. 16 No. 16, pp.1741-1754.

Certo, S.T., Withers, M.C. and Semadeni, M. (2017), “A tale of two effects: using longitudinal data to compare within-and between-firm effects", Strategic Management Journal, Vol. 38 No. 7, pp.1536-1556.

Chan, R.Y. (2005), "Does the natural-resource-based view of the firm apply in an emerging economy? a survey of foreign invested enterprises in China”, Journal of Management Studies, Vol. 42 No. 3, pp.625-672.

Chatterjee, S., Lubatkin, M.H., Lyon, E. and Schulze, W.S. (1999), “Toward a strategic theory of risk premium: moving beyond CAPM", Academy of Management Review, Vol. 24 No. 3, pp.556-567.

Chen, Y.-C., Hung, M. and Wang, Y. (2018), "The effect of mandatory CSR disclosure on firm profitability and social externalities: evidence from China", Journal of Accounting and Economics, Vol. 65 No. 1, pp.169-190.

Collis, D.J. (1994), “Research note: how valuable are organizational capabilities”, Strategic Management Journal, Vol. 15 No. 8, pp.143-152.

Corbett, C.J., Montes-Sancho, M.J. and Kirsch, D.A. (2005), “The financial impact of ISO 9000 certification in the United States: an empirical analysis”, Management Science, Vol. 51 No. 7, pp.1046-1059.

Dangelico, R.M. and Pontrandolfo, P. (2015), “Being 'green and competitive': the impact of environmental actions and collaborations on firm performance”, Business Strategy and the Environment, Vol. 24, pp.413-430.

Daniel, F., Lohrke, F.T., Fornaciari, C.J. and Turner Jr, R.A. (2004), “Slack resources and firm performance: a meta-analysis", Journal of Business Research, Vol. 57 No. 6, pp.565-574.

Darnall, N. and Edwards, D. (2006), "Predicting the cost of environmental management system adoption: the role of capabilities, resources and ownership structure", Strategic Management Journal, Vol. 27 No. 4, pp.301-320.

Darnall, N., Henriques, I. and Sadorsky, P. (2010), “Adopting proactive environmental strategy: the influence of stakeholders and firm size”, Journal of Management Studies, Vol. 47 No. 6, pp.1072-1094.

Delmas, M.A. and Montes-Sancho, M. (2009), "Voluntary agreements to improve environmental quality: symbolic and substantive cooperation”, Strategic Management Journal, Vol. 31 No. 6, pp.575-601.

Delmas, M.A. and Montes-Sancho, M. (2011), “An institutional perspective on the diffusion of international management system standards: the case of the environmental management standard ISO 14001", Business Ethics Quarterly, Vol. 21 No. 1, pp.103-132.

Dosi, G., Nelson, R.R. and Winter, S.G. (2000), The nature and dynamics of organizational capabilities, Oxford University Press, Oxford, UK.

Eisenhardt, K.M. and Martin, J.A. (2000), “Dynamic capabilities: what are they?”, Strategic Management Journal, Vol. 21 No. 10-11, pp.1105-1121.

Feng, T. and Wang, D. (2014), “The influence of environmental management systems on financial performance: 
a moderated-mediation analysis", Journal of Business Ethics, Vol. 135 No. 2, pp.265-278.

Fernández-Muñiz, B., Montes-Peón, J.M. and Vázquez-Ordás, C.J. (2012), “Occupational risk management under the OHSAS 18001 standard: analysis of perceptions and attitudes of certified firms", Journal of Cleaner Production, Vol. 24, pp.36-47.

Flammer, C. (2013), “Corporate social responsibility and shareholder reaction: the environmental awareness of investors", Academy of Management Journal, Vol. 56 No. 3, pp.758-781.

Fry, L.W. and Smith, D.A. (1987), “Congruence, contingency, and theory building”, Academy of Management Review, Vol. 12 No. 1, pp.117-132.

Fryxell, G.E., Lo, C.W.-H. and Chung, S.S. (2004), "Influence of motivations for seeking ISO 14001 certification on perceptions of ems effectiveness in China”, Environmental Management, Vol. 33 No. 2, pp.239-251.

Gaur, V., Fisher, M.L. and Raman, A. (2005), “An econometric analysis of inventory turnover performance in retail services", Management Science, Vol. 51 No. 2, pp.181-194.

Godfrey, P.C., Merrill, C.B. and Hansen, J.M. (2009), “The relationship between corporate social responsibility and shareholder value: an empirical test of the risk management hypothesis", Strategic Management Journal, Vol. 30 No. 4, pp.425-445.

Gray, J.V., Anand, G. and Roth, A.V. (2015), “The influence of ISO 9000 certification on process compliance”, Production and Operations Management, Vol. 24 No. 3, pp.369-382.

He, W., Liu, C., Lu, J. and Cao, J. (2015), “Impacts of ISO 14001 adoption on firm performance: evidence from China", China Economic Review, Vol. 32, pp.43-56.

He, W. and Shen, R. (2019), "ISO 14001 certification and corporate technological innovation: evidence from Chinese firms", Journal of Business Ethics, Vol. 158 No. 1, pp.97-117.

Heinkel, R., Kraus, A. and Zechner, J. (2001), “The effect of green investment on corporate behavior", Journal of Financial and Quantitative Analysis, Vol. 36 No. 4, pp.431-449.

Hendricks, K.B., Singhal, V.R. and Zhang, R.R. (2009), “The effect of operational slack, diversification, and vertical relatedness on the stock market reaction to supply chain disruptions", Journal of Operations Management, Vol. 27 No. 3, pp.233-246.

Heras-Saizarbitoria, I., Arana Landín, G. and Molina-Azorín, J.F. (2011a), "Do drivers matter for the benefits of ISO 14001?", International Journal of Operations \& Production Management, Vol. 31 No. 2, pp.192-216.

Heras-Saizarbitoria, I. and Boiral, O. (2013), "ISO 9001 and ISO 14001: towards a research agenda on management system standards”, International Journal of Management Reviews, Vol. 15 No. 1, pp.47-65.

Heras-Saizarbitoria, I., Molina-Azorín, J.F. and Dick, G.P. (2011b), "ISO 14001 certification and financial performance: selection-effect versus treatment-effect”, Journal of Cleaner Production, Vol. 19 No. 1, pp.1-12.

Hollenbeck, J.R. and Wright, P.M. (2017), "Harking, sharking, and tharking: making the case for post hoc analysis of scientific data", Journal of Management, Vol. 43 No. 1, pp.5-18

Hudson, J. and Orviska, M. (2013), “Firms' adoption of international standards: one size fits all?", Journal of Policy Modeling, Vol. 35 No. 2, pp.289-306.

Ivanova, A., Gray, J. and Sinha, K. (2014), “Towards a unifying theory of management standard implementation: the case of ISO 9001/ISO 14001”, International Journal of Operations \& Production Management, Vol. 34 No. 10, pp.1269-1306.

Jayasinghe, M. (2016), “The operational and signaling benefits of voluntary labor code adoption: 
reconceptualizing the scope of human resource management in emerging economies", Academy of Management Journal, Vol. 59 No. 2, pp.658-677.

Judge, W.Q. and Douglas, T.J. (1998), "Performance implications of incorporating natural environmental issues into the strategic planning process: an empirical assessment", Journal of Management Studies, Vol. 35 No. 2, pp.241-262.

King, A.A., Lenox, M.J. and Terlaak, A. (2005), "The strategic use of decentralized institutions: exploring certification with the ISO 14001 management standard", Academy of Management Journal, Vol. 48 No. 6 , pp.1091-1106.

Kitazawa, S. and Sarkis, J. (2000), “The relationship between ISO 14001 and continuous source reduction programs", International Journal of Operations \& Production Management, Vol. 20 No. 2, pp.225-248.

Klassen, R. and McLaughlin, C. (1996), "The impact of environmental management on firm performance", Management Science, Vol. 42 No. 8, pp.1199-1214.

Koe Hwee Nga, J. (2009), "The influence of ISO 14000 on firm performance”, Social Responsibility Journal, Vol. 5 No. 3, pp.408-422.

Lam, H.K. (2018), "Doing good across organizational boundaries: sustainable supply chain practices and firms' financial risk”, International Journal of Operations \& Production Management, Vol. 38 No. 12, pp.23892412.

Lechner, M. (2011), "The estimation of causal effects by difference-in-difference methods", Foundations and Trends ${ }^{\circledR}$ in Econometrics, Vol. 4 No. 3, pp.165-224.

Leuven, E. and Sianesi, B. (2018), "Psmatch2: Stata module to perform full Mahalanobis and propensity score matching, common support graphing, and covariate imbalance testing", available at: https://sociorepec.org/publication.xml?h=repec:boc:bocode:s432001\&l=en (accessed DD Month Year)

Levine, D.I. and Toffel, M.W. (2010), "Quality management and job quality: how the ISO 9001 standard for quality management systems affects employees and employers”, Management Science, Vol. 56 No. 6 , pp.978-996.

Li, D., Zheng, M., Cao, C., Chen, X., Ren, S. and Huang, M. (2017), "The impact of legitimacy pressure and corporate profitability on green innovation: evidence from China top 100", Journal of Cleaner Production, Vol. 141, pp.41-49.

Lo, C.K., Tang, C.S., Zhou, Y., Yeung, A.C. and Fan, D. (2018), "Environmental incidents and the market value of firms: an empirical investigation in the Chinese context", Manufacturing \& Service Operations Management, Vol. 20 No. 3, pp.422-439.

Lo, C.K.Y., Pagell, M., Fan, D., Wiengarten, F. and Yeung, A.C.L. (2014), “OHSAS 18001 certification and operating performance: the role of complexity and coupling", Journal of Operations Management, Vol. 32 No. 5, pp.268-280.

Lo, C.K.Y., Wiengarten, F., Humphreys, P., Yeung, A.C.L. and Cheng, T.C.E. (2013), “The impact of contextual factors on the efficacy of ISO 9000 adoption", Journal of Operations Management, Vol. 31 No. 5, pp.229-235.

Lo, C.K.Y., Yeung, A.C.L. and Cheng, T.C.E. (2009), "ISO 9000 and supply chain efficiency: empirical evidence on inventory and account receivable days", International Journal of Production Economics, Vol. 118 No. 2, pp.367-374.

Lucas, M.T. and Noordewier, T.G. (2016), "Environmental management practices and firm financial 
performance: the moderating effect of industry pollution-related factors", International Journal of Production Economics, Vol. 175, pp.24-34.

Luo, X. (2007), “Consumer negative voice and firm-idiosyncratic stock returns”, Journal of Marketing, Vol. 71 No. 3, pp.75-88.

Luo, X. and Bhattacharya, C.B. (2009), "The debate over doing good: corporate social performance, strategic marketing levers, and firm-idiosyncratic risk”, Journal of Marketing, Vol. 73 No. 6, pp.198-213.

Melnyk, S.A., Sroufe, R.P. and Calantone, R. (2003), “Assessing the impact of environmental management systems on corporate and environmental performance", Journal of Operations Management, Vol. 21 No. 3, pp.329-351.

Menguc, B., Auh, S. and Ozanne, L. (2010), “The interactive effect of internal and external factors on a proactive environmental strategy and its influence on a firm's performance", Journal of Business Ethics, Vol. 94 No. 2, pp.279-298.

Miller, K.D. and Bromiley, P. (1990), "Strategic risk and corporate performance: an analysis of alternative risk measures", Academy of Management Journal, Vol. 33 No. 4, pp.756-779.

Mishina, Y., Pollock, T.G. and Porac, J.F. (2004), “Are more resources always better for growth? resource stickiness in market and product expansion”, Strategic Management Journal, Vol. 25 No. 12, pp.1179-1197.

Mishra, S. and Modi, S.B. (2012), "Positive and negative corporate social responsibility, financial leverage, and idiosyncratic risk", Journal of Business Ethics, Vol. 117 No. 2, pp.431-448.

Naveh, E. and Marcus, A. (2005), “Achieving competitive advantage through implementing a replicable management standard: installing and using ISO 9000”, Journal of Operations Management, Vol. 24 No. 1 , pp.1-26.

Nishitani, K. (2009), “An empirical study of the initial adoption of ISO 14001 in Japanese manufacturing firms", Ecological Economics, Vol. 68 No. 3, pp.669-679.

Ortiz-de-Mandojana, N. and Bansal, P. (2016), "The long-term benefits of organizational resilience through sustainable business practices”, Strategic Management Journal, Vol. 37 No. 8, pp.1615-1631.

Palmer, T.B. and Wiseman, R.M. (1999), "Decoupling risk taking from income stream uncertainty: a holistic model of risk", Strategic Management Journal, Vol. 20 No. 11, pp.1037-1062.

Peng, M.W. and Su, W. (2014), "Cross-listing and the scope of the firm”, Journal of World Business, Vol. 49 No. $1, \mathrm{pp} .42-50$.

Potoski, M. and Prakash, A. (2005a), “Covenants with weak swords: ISO 14001 and facilities' environmental performance", Journal of Policy Analysis and Management, Vol. 24 No. 4, pp.745-769.

Potoski, M. and Prakash, A. (2005b), “Green clubs and voluntary governance: ISO 14001 and firms' regulatory compliance", American Journal of Political Science, Vol. 49 No. 2, pp.235-248.

Przychodzen, J. and Przychodzen, W. (2015), "Relationships between eco-innovation and financial performance-evidence from publicly traded companies in Poland and Hungary", Journal of Cleaner Production, Vol. 90, pp.253-263.

Rabinovich, E., Dresner, M.E. and Evers, P.T. (2003), “Assessing the effects of operational processes and information systems on inventory performance", Journal of Operations Management, Vol. 21 No. 1, pp.63-80.

Reverte, C. (2009), “Determinants of corporate social responsibility disclosure ratings by Spanish listed firms", Journal of Business Ethics, Vol. 88 No. 2, pp.351-366.

Rosenbaum, P.R. and Rubin, D.B. (1983), “The central role of the propensity score in observational studies for 
causal effects", Biometrika, Vol. 70 No. 1, pp.41-55.

Russo, M.V. (2009), "Explaining the impact of ISO 14001 on emission performance: a dynamic capabilities perspective on process and learning”, Business Strategy and the Environment, Vol. 18 No. 5, pp.307-319.

Sadovnikova, A. and Pujari, A. (2017), “The effect of green partnerships on firm value”, Journal of the Academy of Marketing Science, Vol. 45 No. 2, pp.251-267.

Sanchez, R. and Mahoney, J.T. (1996), "Modularity, flexibility, and knowledge management in product and organization design”, Strategic Management Journal, Vol. 17 No. S2, pp.63-76.

Schreyögg, G. and Kliesch-Eberl, M. (2007), "How dynamic can organizational capabilities be? towards a dualprocess model of capability dynamization”, Strategic Management Journal, Vol. 28 No. 9, pp.913-933.

Semenova, N. and Hassel, L.G. (2008), "Financial outcomes of environmental risk and opportunity for US companies”, Sustainable Development, Vol. 16 No. 3, pp.195-212.

Sharfman, M.P. and Fernando, C.S. (2008), "Environmental risk management and the cost of capital”, Strategic Management Journal, Vol. 29 No. 6, pp.569-592.

Sharma, S. and Ruud, A. (2003), "On the path to sustainability: integrating social dimensions into the research and practice of environmental management”, Business Strategy and the Environment, Vol. 12 No. 4, pp.205-214.

Shin, H.-H. and Stulz, R.M. (2000), "Firm value, risk, and growth opportunities”, Working Paper No. 7808, National Bureau of Economic Research, Cambridge, July.

Sianesi, B. (2004), "An evaluation of the Swedish system of active labor market programs in the 1990s", Review of Economics and Statistics, Vol. 86 No. 1, pp.133-155.

Simpson, D., Power, D. and Klassen, R. (2012), "When one size does not fit all: a problem of fit rather than failure for voluntary management standards”, Journal of Business Ethics, Vol. 110 No. 1, pp.85-95.

Sitkin, S.B. and Pablo, A.L. (1992), "Reconceptualizing the determinants of risk behavior”, Academy of Management Review, Vol. 17 No. 1, pp.9-38.

Smith, J.A. and Todd, P. (2005), “Does matching overcome LaLonde's critique of nonexperimental estimators?”, Journal of Econometrics, Vol. 125 No. 1-2, pp.305-353.

Sousa, R. and Voss, C.A. (2008), “Contingency research in operations management practices", Journal of Operations Management, Vol. 26 No. 6, pp.697-713.

Su, H.-C., Dhanorkar, S. and Linderman, K. (2015), “A competitive advantage from the implementation timing of ISO management standards", Journal of Operations Management, Vol. 37, pp.31-44.

Toffel, M.W., (2005), "Voluntary environmental management initiatives: smoke signals or smoke screens?”, $\mathrm{PhD}$ dissertation, University of California, Berkeley.

Varadarajan, R. (2017), "Innovating for sustainability: a framework for sustainable innovations and a model of sustainable innovations orientation”, Journal of the Academy of Marketing Science, Vol. 45 No. 1, pp.14-36.

Wang, H. and Qian, C. (2011), "Corporate philanthropy and corporate financial performance: the roles of stakeholder response and political access", Academy of Management Journal, Vol. 54 No. 6, pp.1159-1181.

Wernerfelt, B. (1984), “A resource-based view of the firm”, Strategic Management Journal, Vol. 5 No. 2 , pp.171-180.

Xue, L., Ray, G. and Sambamurthy, V. (2012), "Efficiency or innovation: how do industry environments moderate the effects of firms' IT asset portfolios?”, MIS Quarterly, Vol. 36 No. 2, pp.509-582.

Yu, W. and Ramanathan, R. (2015), “An empirical examination of stakeholder pressures, green operations 
practices and environmental performance", International Journal of Production Research, Vol. 53 No. 21, pp.6390-6407.

Zeng, S.X., Xie, X., Tam, C.M. and Wan, T. (2008), "Competitive priorities of manufacturing firms for internationalization: an empirical research", Measuring Business Excellence, Vol. 12 No. 3, pp.44-55.

Zhang, D., Linderman, K. and Schroeder, R.G. (2012), "The moderating role of contextual factors on quality management practices”, Journal of Operations Management, Vol. 30 No. 1, pp.12-23.

Zhao, X., Li, Y. and Flynn, B.B. (2013), "The financial impact of product recall announcements in China", International Journal of Production Economics, Vol. 142 No. 1, pp.115-123.

Zheng, W., Singh, K. and Mitchell, W. (2015), "Buffering and enabling: the impact of interlocking political ties on firm survival and sales growth", Strategic Management Journal, Vol. 36 No. 11, pp.1615-1636. 
Figure 1. Buffering and enabling capabilities

\begin{tabular}{|c|c|}
\hline $\begin{array}{c}\text { (3) Enabling Advantage } \\
\text { - High financial risk } \\
\text { - High sales growth } \\
\text { Trade-off } \\
\end{array}$ & $\begin{array}{l}\text { (4) Competitive Advantage } \\
\text { - Low financial risk } \\
\text { - High sales growth }\end{array}$ \\
\hline $\begin{array}{c}\text { (1) Competitive Disadvantage } \\
\text { - High financial risk } \\
\text { - Low sales growth }\end{array}$ & $\begin{array}{c}\text { (2) Buffering Advantage } \\
\text { - Low financial risk } \\
\text { - Low sales growth } \\
\text { Trade-off }\end{array}$ \\
\hline
\end{tabular}

Level of buffering capability 
Table I. Summary statistics (used in propensity score matching)

\begin{tabular}{|c|c|c|c|c|c|}
\hline Variable & Measure & Mean & SD & Min & Max \\
\hline $\begin{array}{l}\text { Adopt ISO } 14001 \text { this } \\
\text { year }\end{array}$ & $\begin{array}{l}\text { Dummy coded as “ } 1 \text { ” if firm } \\
\text { adopts ISO } 14001 \text { this year }\end{array}$ & 0.060 & 0.2384 & 0.000 & 1.000 \\
\hline $\begin{array}{l}\text { Average financial risk } \\
(t-1 \& t-2)\end{array}$ & RMSE from Fama-French model & 0.025 & 0.0172 & 0.009 & 0.930 \\
\hline $\begin{array}{l}\text { Average sales growth } \\
(t-1 \& t-2)\end{array}$ & Change in sales volume & 0.117 & 0.3344 & -6.953 & 3.719 \\
\hline Have ISO $9001(t-1)$ & $\begin{array}{l}\text { Dummy coded as " } 1 \text { ” if firm has } \\
\text { adopted ISO } 9001\end{array}$ & 0.294 & 0.4556 & 0.000 & 1.000 \\
\hline Have OHS $18001(t-1)$ & $\begin{array}{l}\text { Dummy coded as " } 1 \text { " if firm has } \\
\text { adopted OHS } 18001\end{array}$ & 0.021 & 0.1425 & 0.000 & 1.000 \\
\hline Cross-listing $(t-1)$ & $\begin{array}{l}\text { Dummy coded as " } 1 \text { " if firm is } \\
\text { listed in Hong Kong or US stock } \\
\text { markets }\end{array}$ & 0.029 & 0.1669 & 0.000 & 1.000 \\
\hline Slack $(t-1)$ & Sales income/total assets & 2.481 & 5.7499 & 0.011 & 204.742 \\
\hline Firm age $(t-1)$ & This year, established year & 2.499 & 0.4458 & 0.000 & 3.555 \\
\hline $\operatorname{ROA}(t-1)$ & Profit/total assets & 0.019 & 0.6452 & -48.316 & 10.401 \\
\hline $\operatorname{ROE}(t-1)$ & Profit/equity & 0.038 & 3.4266 & -141.763 & 204.690 \\
\hline Leverage $(t-1)$ & Debt/total assets & 0.516 & 1.0984 & 0.007 & 63.971 \\
\hline Size $(t-1)$ & Sales volume (in log) & 20.935 & 1.4848 & 13.044 & 27.218 \\
\hline Inventory turnover $(t-1)$ & $\begin{array}{l}\text { Costs of goods sold/average } \\
\text { inventory level }\end{array}$ & 12.671 & 570.2820 & 0.002 & 45257.290 \\
\hline CSR disclosure & $\begin{array}{l}\text { Dummy coded as " } 1 \text { ” if firm } \\
\text { issues CSR report this year }\end{array}$ & 0.128 & 0.3337 & 0.000 & 1.000 \\
\hline
\end{tabular}

There are a total of 6,316 firm-year observations. The sample incudes firms that never adopted ISO 14001 in all years, and firms that adopted ISO 14001 in and before the adoption year. 
Table II. Correlation matrix (used in propensity score matching)

\begin{tabular}{|c|c|c|c|c|c|c|c|c|c|c|c|c|c|c|c|}
\hline \multicolumn{2}{|c|}{ Variable } & \multirow{2}{*}{$\frac{(1)}{1.000}$} & \multirow[t]{2}{*}{ (2) } & \multirow[t]{2}{*}{ (3) } & \multirow[t]{2}{*}{ (4) } & \multirow[t]{2}{*}{ (5) } & \multirow[t]{2}{*}{ (6) } & \multirow[t]{2}{*}{ (7) } & \multirow[t]{2}{*}{$(8)$} & \multirow[t]{2}{*}{ (9) } & \multirow[t]{2}{*}{ (10) } & \multirow[t]{2}{*}{ (11) } & \multirow[t]{2}{*}{ (12) } & \multirow[t]{2}{*}{ (13) } & \multirow[t]{2}{*}{ (14) } \\
\hline (1) & Adopt ISO 14001 this year & & & & & & & & & & & & & & \\
\hline (2) & Average financial risk $(t-1 \& t-2)$ & 0.002 & 1.000 & & & & & & & & & & & & \\
\hline (3) & Average sales growth $(t-1 \& t-2)$ & 0.017 & 0.015 & 1.000 & & & & & & & & & & & \\
\hline (4) & Have ISO $9001(t-1)$ & $\begin{array}{c}0.064 \\
{ }_{(* * *)}\end{array}$ & -0.007 & -0.002 & 1.000 & & & & & & & & & & \\
\hline (5) & Have OHS $18001(t-1)$ & $\begin{array}{c}-0.018 \\
(* *)\end{array}$ & -0.005 & 0.015 & $\begin{array}{c}0.282 \\
(* * *)\end{array}$ & 1.000 & & & & & & & & & \\
\hline (6) & Cross-listing $(t-1)$ & -0.007 & -0.016 & 0.003 & -0.011 & -0.003 & 1.000 & & & & & & & & \\
\hline & Slack $(t-1)$ & $\begin{array}{c}0.019 \\
\left(^{*}\right)\end{array}$ & 0.000 & $\begin{array}{c}-0.034 \\
{ }^{(* * *)}\end{array}$ & $\begin{array}{c}0.062 \\
(* * *)\end{array}$ & 0.005 & $\begin{array}{c}-0.037 \\
{ }^{(* *)}\end{array}$ & 1.000 & & & & & & & \\
\hline & Firm age $(t-1)$ & $\begin{array}{c}-0.042 \\
{ }_{(* * *)}\end{array}$ & $\begin{array}{c}-0.052 \\
{ }^{(* * *)}\end{array}$ & $\begin{array}{c}-0.068 \\
{ }^{(* * *)}\end{array}$ & 0.011 & $\begin{array}{c}0.037 \\
{ }_{(* * *)}\end{array}$ & $\begin{array}{c}0.065 \\
{ }_{(* * *)}\end{array}$ & $\begin{array}{c}-0.098 \\
\left.{ }^{* * *}\right)\end{array}$ & 1.000 & & & & & & \\
\hline (9) & $\operatorname{ROA}(t-1)$ & 0.006 & 0.002 & $\begin{array}{c}0.037 \\
{ }_{(* *)}\end{array}$ & $\begin{array}{c}0.021 \\
{ }_{(* *)}\end{array}$ & 0.012 & 0.001 & 0.022 & -0.014 & 1.000 & & & & & \\
\hline (10) & $\operatorname{ROE}(t-1)$ & -0.001 & 0.001 & $\begin{array}{c}-0.047 \\
{ }_{(* * *)}\end{array}$ & 0.002 & -0.001 & -0.001 & -0.001 & 0.010 & $\begin{array}{c}0.413 \\
{ }^{(* * *)}\end{array}$ & 1.000 & & & & \\
\hline (11) & Leverage $(t-1)$ & -0.018 & $\begin{array}{c}0.022 \\
\left.{ }^{*}\right)\end{array}$ & $\begin{array}{c}-0.054 \\
{ }_{(* * *)}\end{array}$ & $\begin{array}{c}-0.032 \\
{ }^{(* * *)}\end{array}$ & -0.007 & -0.002 & $\begin{array}{c}-0.071 \\
{ }^{(* *)}\end{array}$ & $\begin{array}{c}0.047 \\
{ }^{(* *)}\end{array}$ & $\begin{array}{c}-0.426 \\
\left.{ }^{* * *}\right)\end{array}$ & 0.002 & 1.000 & & & \\
\hline (12) & Size $(t-1)$ & $\begin{array}{c}0.023 \\
(* *)\end{array}$ & $\begin{array}{c}-0.100 \\
{ }^{(* * *)}\end{array}$ & $\begin{array}{c}0.309 \\
(* * *)\end{array}$ & -0.001 & $\begin{array}{c}0.054 \\
{ }_{(* * *)}\end{array}$ & $\begin{array}{c}0.207 \\
{ }_{(* * *)}\end{array}$ & $\begin{array}{c}-0.147 \\
{ }^{(* * *)}\end{array}$ & $\begin{array}{c}0.090 \\
{ }^{(* * *)}\end{array}$ & $\begin{array}{c}0.035 \\
{ }^{(* * *)}\end{array}$ & $\begin{array}{c}-0.062 \\
\left.{ }^{* * *}\right)\end{array}$ & $\begin{array}{c}-0.106 \\
{ }^{(* * *)}\end{array}$ & 1.000 & & \\
\hline (13) & Inventory turnover $(t-l)$ & -0.003 & 0.002 & 0.002 & -0.008 & -0.002 & -0.002 & -0.005 & 0.012 & 0.006 & 0.001 & -0.005 & -0.004 & 1.000 & \\
\hline (14) & CSR disclosure & -0.002 & $\begin{array}{c}-0.043 \\
{ }^{(* * *)}\end{array}$ & $\begin{array}{c}0.040 \\
(* * *)\end{array}$ & $\begin{array}{c}0.013 \\
\left(^{*}\right)\end{array}$ & $\begin{array}{c}0.054 \\
{ }_{(* * *)}\end{array}$ & $\begin{array}{c}0.165 \\
{ }_{(* * *)}\end{array}$ & 0.010 & $\begin{array}{c}0.160 \\
{ }^{(* * *)}\end{array}$ & 0.014 & -0.002 & -0.016 & $\begin{array}{c}0.303 \\
{ }_{(* * *)}\end{array}$ & -0.005 & 1.000 \\
\hline
\end{tabular}

${ }^{* * *} \mathrm{p}<0.01,{ }^{* *} \mathrm{p}<0.05,{ }^{*} \mathrm{p}<0.1$; The sample includes firms that never adopted ISO 14001 in all years, and firms that adopted ISO 14001 in and before the adoption year. 
Table III. Probit model for estimating propensity scores

Probit coefficient

Dependent variable: adopt ISO14001 this year

Average financial risk $(t-1 \& t-2)$

Average sales growth $(t-1 \& t-2)$

Have ISO $9001(t-1)$

Have OHS $18001(t-1)$

Cross-listing $(t-1)$

Slack $(t-1)$

Firm age $(t-1)$

$\operatorname{ROA}(t-1)$

$\operatorname{ROE}(t-1)$

Leverage ( $t-1)$

Size $(t-1)$

Inventory turnover $(t-1)$

CSR disclosure

Observations (firm-year)

Number of firms

Pseudo-R2

Wald2

$$
1.479
$$

[1.0366]

$-0.133$

[0.1244]

$0.422^{* * *}$

[0.0649]

$0.755^{* * *}$

[0.1566]

$-0.269$

[0.1879]

$-0.003$

[0.0046]

$-0.314^{* * *}$

[0.0683]

$-0.035^{* * *}$

0.053

[0.1869]

0.006

0.005

[0.0101]

0.001

$-0.455^{* * *}$

[0.1676]

$0.103^{* * *}$

[0.0303]

$-0.02^{* *}$

[0.0076]

0.01

[0.0959]

$-0.051^{* * *}$

$0.012^{* * *}$

$-0.002^{* *}$

0.001
5753

957

0.13

316.53

${ }^{* * *} \mathrm{p}<0.01,{ }^{* *} \mathrm{p}<0.05,{ }^{*} \mathrm{p}<0.1$; Brackets contain standard errors; The model includes year, industry, and region dummies. 
Table IV. Balancing test results

\begin{tabular}{lllllll}
\hline & \multicolumn{3}{c}{ Before matching } & \multicolumn{3}{c}{ After matching } \\
& Treated & Control & $\mathrm{T}$ (p-value) & Treated & Control & $\mathrm{T}(\mathrm{p}$-value $)$ \\
\hline Financial risk $(t-1 \& t-2)$ & 0.02485 & 0.02422 & $0.63(0.528)$ & 0.02452 & 0.02309 & $1.64(0.101)$ \\
Sales growth $(t-1 \& t-2)$ & 0.16021 & 0.12362 & $2.09(0.037)$ & 0.16294 & 0.12147 & $2.06(0.039)$ \\
Have ISO 9001 $(t-1)$ & 0.52589 & 0.2558 & $11.18 \mathrm{~g}(0)$ & 0.49853 & 0.53079 & $-0.84(0.4)$ \\
Have OHS 18001 $(t-1)$ & 0.08719 & 0.01006 & $11.17(0)$ & 0.06158 & 0.03812 & $1.41(0.16)$ \\
Cross-listed $(t-1)$ & 0.0218 & 0.0312 & $-1.00(0.316)$ & 0.02346 & 0.0088 & $1.52(0.129)$ \\
Slack $(t-1)$ & 2.8024 & 2.5588 & $0.69(0.492)$ & 2.8286 & 3.106 & $-0.74(0.463)$ \\
Age $(t-1)$ & 2.2998 & 2.521 & $-9.40(0)$ & 2.3247 & 2.3603 & $-0.99(0.325)$ \\
ROA $(t-1)$ & 0.04299 & 0.02874 & $1.11(0.268)$ & 0.04279 & 0.0329 & $1.30(0.195)$ \\
ROE $(t-1)$ & 0.06303 & 0.03574 & $0.12(0.902)$ & 0.06213 & 0.1083 & $0.12(0.902)$ \\
Leverage $(t-1)$ & 0.42524 & 0.49821 & $-2.61(0.009)$ & 0.42759 & 0.41543 & $0.73(0.464)$ \\
Size $(t-1)$ & 21.117 & 20.925 & $2.0(0.016)$ & 21.126 & 20.948 & $1.71(0.088)$ \\
Inventory turnover $(t-1)$ & 4.3321 & 17.017 & $-0.33(0.738)$ & 4.4215 & 4.3721 & $0.19(0.848)$ \\
CSR disclosure $(t-1)$ & 0.15804 & 0.13151 & $1.43(0.154)$ & 0.16129 & 0.1349 & $0.97(0.333)$ \\
\hline
\end{tabular}

The model includes year, industry, and region dummies. 
Table V. DID results

\begin{tabular}{|c|c|c|c|c|}
\hline & \multicolumn{2}{|c|}{ Financial risk } & \multicolumn{2}{|c|}{ Sales growth } \\
\hline & (1) & (2) & (3) & (4) \\
\hline Treat & - & - & - & - \\
\hline Post & $\begin{array}{c}-0.0006 \\
{[0.00046]}\end{array}$ & $\begin{array}{c}-0.0008^{*} \\
{[0.00043]}\end{array}$ & $\begin{array}{c}0.0307^{*} \\
{[0.01586]}\end{array}$ & $\begin{array}{c}-0.0066 \\
{[0.01710]}\end{array}$ \\
\hline Treat* Post & $\begin{array}{l}-0.0013^{* * *} \\
{[0.00044]}\end{array}$ & - & $\begin{array}{l}-0.0500^{* * *} \\
{[0.01734]}\end{array}$ & - \\
\hline Treat*Post - years $0 / 1 / 2$ & & $\begin{array}{l}-0.0011^{* *} \\
{[0.00046]}\end{array}$ & & $\begin{array}{c}-0.0017 \\
{[0.01827]}\end{array}$ \\
\hline Treat*Post - years 3/4/5 & & $\begin{array}{l}-0.0012^{* *} \\
{[0.00049]}\end{array}$ & & $\begin{array}{l}-0.0480^{* *} \\
{[0.01912]}\end{array}$ \\
\hline Treat*Post - years 6/7/8 & & $\begin{array}{l}-0.0021^{* * *} \\
{[0.00064]}\end{array}$ & & $\begin{array}{l}-0.0951^{* * *} \\
{[0.02527]}\end{array}$ \\
\hline Financial risk & - & - & $\begin{array}{l}2.3667^{* * *} \\
{[0.51391]}\end{array}$ & $\begin{array}{l}2.3423^{* * *} \\
{[0.51368]}\end{array}$ \\
\hline Sales growth & $\begin{array}{l}0.0015^{* * *} \\
{[0.00033]}\end{array}$ & $\begin{array}{l}0.0015^{* * *} \\
{[0.00033]}\end{array}$ & - & - \\
\hline Constant & $\begin{array}{l}0.0201^{* * *} \\
{[0.00038]}\end{array}$ & $\begin{array}{l}0.0201^{* * *} \\
{[0.00039]}\end{array}$ & $\begin{array}{l}0.1014^{* * *} \\
{[0.01844]}\end{array}$ & $\begin{array}{l}0.0989^{* * *} \\
{[0.01843]}\end{array}$ \\
\hline Number of firms & 682 & 682 & 682 & 682 \\
\hline Observations & 6556 & 6556 & 6556 & 6556 \\
\hline $\mathrm{R} 2$ & 0.25 & 0.25 & 0.08 & 0.08 \\
\hline Wald test $\left(\beta_{012}=\beta_{345}\right)$ & & 0.07 & & $7.27^{* * *}$ \\
\hline Wald test $\left(\beta_{345}=\beta_{678}\right)$ & & 2.57 & & $4.04^{* *}$ \\
\hline Wald test $\left(\beta_{012}=\beta_{678}\right)$ & & $2.81^{*}$ & & $13.90^{* * *}$ \\
\hline Wald test $\left(\beta_{012}=\beta_{345}=\beta_{678}\right)$ & & 1.54 & & $7.67^{* * *}$ \\
\hline
\end{tabular}

${ }^{* * *} \mathrm{p}<0.01,{ }^{* *} \mathrm{p}<0.05,{ }^{*} \mathrm{p}<0.1$; Brackets contain standard errors; The model includes year, industry, and region dummies. F statistics are presented for the Wald test. 
Table VI. Multi-group DID

\begin{tabular}{|c|c|c|c|c|c|c|c|c|}
\hline & \multicolumn{2}{|c|}{ Financial risk } & \multicolumn{2}{|c|}{ Financial risk } & \multicolumn{2}{|c|}{ Sales growth } & \multicolumn{2}{|c|}{ Sales growth } \\
\hline & Early certified & Late certified & High-polluting & Low-polluting & Early certified & Late certified & High-polluting & Low-polluting \\
\hline Treat & - & - & - & - & - & - & - & - \\
\hline \multirow{2}{*}{ Post } & $-0.0021^{* *}$ & -0.0003 & -0.0006 & -0.0006 & $0.0531^{* *}$ & -0.0340 & -0.0095 & $0.0563^{* * *}$ \\
\hline & {$[0.00082]$} & {$[0.00064]$} & {$[0.00054]$} & [0.00059] & [0.02480] & {$[0.0363]$} & [0.02379] & [0.02129] \\
\hline \multirow{2}{*}{ Treat*Post } & $-0.0019^{* *}$ & -0.0003 & $-0.0015^{* * *}$ & $-0.0012^{*}$ & $-0.0567^{* *}$ & -0.0445 & $-0.0435^{*}$ & $-0.00483^{* *}$ \\
\hline & {$[0.00083]$} & {$[0.00057]$} & [0.00057] & {$[0.00065]$} & [0.02491] & {$[0.03340]$} & {$[0.02551]$} & {$[0.02597]$} \\
\hline Financial risk & - & - & - & - & $\begin{array}{l}2.3819^{* * *} \\
{[0.57474]}\end{array}$ & $1.9616^{*}[1.16528]$ & $\begin{array}{l}2.6612^{* * *} \\
{[0.85642]}\end{array}$ & $\begin{array}{l}2.2184^{* * *} \\
{[0.64356]}\end{array}$ \\
\hline Sales growth & $\begin{array}{l}0.0026^{* * *} \\
{[0.00047]}\end{array}$ & $\begin{array}{c}0.0007^{*} \\
{[0.00042]}\end{array}$ & $\begin{array}{l}0.0014^{* * *} \\
{[0.00047]}\end{array}$ & $\begin{array}{c}0.0017^{* *} \\
{[0.00049]}\end{array}$ & - & - & - & - \\
\hline \multirow{2}{*}{ Constant } & $0.0200^{* * *}$ & $0.0203^{* * *}$ & $0.0196^{* * *}$ & $0.0206^{* * *}$ & $0.0900^{* * *}$ & $0.1116^{* * *}$ & $0.1112^{* * *}$ & $0.0891^{* * *}$ \\
\hline & {$[0.00063]$} & {$[0.00059]$} & [0.00049] & [0.00059] & {$[0.02171]$} & [0.03885] & {$[0.02737]$} & {$[0.02518]$} \\
\hline Number of firms & 275 & 276 & 295 & 387 & 275 & 276 & 295 & 387 \\
\hline Observations & 3020 & 2325 & 2985 & 3571 & 3020 & 2325 & 2985 & 3571 \\
\hline R2 & 0.21 & 0.32 & 0.32 & 0.22 & 0.12 & 0.05 & 0.10 & 0.07 \\
\hline
\end{tabular}

${ }^{* * *} \mathrm{p}<0.01,{ }^{* *} \mathrm{p}<0.05,{ }^{*} \mathrm{p}<0.1$; Brackets contain standard errors; The model includes year, industry, and region dummies. 
